Бојана Стаменковић Рудић* Београд

\title{
ТРАНСХУМАНИЗАМ И АНАЛИТИЧКА ПСИХОЛОГИЈА
}

У раду је изнет критички осврт на трансхуманистички покрет са аспекта аналитичке психологије.

Сагледане су идеје и ризици ове праксе кроз поље преклапања са неким од базичних парадигми Јунговог учења: соларну и лунарну савест, психолошке аспекте ероса и логоса, као и директивно и фантазматско мишљење. Коришћени су ставови релевантних аутора у теорији аналитичке психологије, почев од творца ове школе, па до наших савременика. Рад износи и психолошку интерпретацију књижевног дела које је релевантно за ову тему, Франкенштајн или модерни Прометеј, ауторке Мери Шели. Овом делу се може приписати предиктивни карактер у односу на тему трансхуманизма, а инспирисало је настанак бројних студија које се баве сагледавањем ове новеле кроз разнородне културолошке аспекте. У раду је обухваћен део ових критичких сагледавања, са нагласком на тематику која се може повезати са могућим ризицима трансхуманистичког покрета. У оквиру ове тематике, мит о Прометеју је инспирисао различите начине његове интерпретације; наилазимо на разилажења у његовом разумевању између припадника психолошке мисли, а посебно у дијалогу заговорника трансхуманизма и биоконзервативизма. Дихотомије у начину сагледавања Прометејског синдрома и Прометејске жудње доводе до различитих приступа у примени амплификације, једне од метода рада у аналитичкој психологији, у сагледавању психолошког материјала. Овде се отвара поље које поларизује ставове у разматрању идеја трансхуманизма и целе наше културе.

У закључку рада, указано је на нужност балансираног присуства маскулиних и фемининих одлика у нашем бављењу идејама,

stamenkovicbojana@yahoo.com

спец. психијатрије, системски породични терапеут, аналитичар и супервизор у модалитету аналитичке психологије. Ради у приватној пракси, ул. Страхињића Бана, бр. 41/9, Београд 
емоционалном доживљавању и у нашем свесном деловању. Занемаривање фемининих психолошких принципа, актуелно присутно у нашој култури, у будућности би могло да доведе до остварења садашњих ризика и до великих деструктивних помака.

Кључне речи: трансхуманизам, аналитичка психологија, Прометејев синдром, психологија женског и мушког.

\section{1. Увод}

Професор Џејмс Биркс (James Birx) је својим предавањем Франкенитајн: критичке рефлексије (Frankenstein: Critical Reflections), децембра 2015. године, отворио широк простор за промишљање о еволуцији човека у будућности. Сведоци смо убрзаног развоја технологије, посебно на плану генетског инжењеринга и нанотехнологије, а мењање људског генома и стварање нових врста у процесу еволуције - ускоро ће постати наша реалност. Идеја да се еволуција човека може усмерити у одређеном правцу и да се менталне и физичке способности људске врсте могу убрзано побољшавати, представља премису трансхуманистичког покрета који се формира током последњих тридесетак година. Имагинација бројних генерација наших претходника се сада отелотворује, те у многим аспектима научног прогреса можемо да препознамо остварење најлепших снова наших предака. У исто време, међутим, историјска перспектива нам пружа знања о злоупотреби научних достигнућа и потребно је да не пропустимо да усвојимо подуке из почињених грешака. У складу са овим, трансхуманистички покрет се бави и истраживањем потенцијалних опасности које коришћење науке може да произведе, чак и са циљем превазилажења базичних ограничења људске врсте.

Садашњост се одликује све убрзанијим креирањем, чини се да су периоди у којима се можемо поуздати у досегнута знања - све краћи, као да се већ тренутак у којем живимо претаче у будућност. Бројни су заступници мисли да је све мање времена за сагледавање дихотомије између предности и ризика које носе научна достигнућа. У стручној јавности се 
отварају бројне дебате о овој теми, а оне се често завршавају пооштравањем поларизације ставова у односу на почетну позицију. Опоненти, привидно парадоксално, деле став о томе да супротна страна пренебрегава сагледавање суштине потреба човечанства и самим тим угрожава опстанак врсте.

Шта све угрожава наш опстанак? Шта све може довести до краја постојања наше врсте? Да ли ће то бити глад, жеђ, метеоролошки удес који не подлеже нашој контроли, потреба за ратовањем која је иманентна људској врсти, по мишљењу психолога? Ове хипотезе, као и бројне друге, нису предмет нашег разматрања. У фокусу наше пажње је једна од најлепших одлика људске врсте - креативност. Бројне психолошке теорије сагледавају нашу потребу за креативношћу као једну од базичних људских тежњи. Она је уткана у данашњи ниво технолошког развоја којег остварује људска врста, а у будућности ће улога креатора, према неким од могућих сценарија у контексту даљег развоја - бити препуштена новој врсти. Дакле, не само да ће генетски инжењеринг и нанотехнологија омогућити да успоримо процес старења (што се постиже контролом свих физиолошких и патолошких процеса у организму), већ ће развој вештачке интелигенције хипотетички довести до стварања самосвесне високо интелигентне нове врсте која ће превазилазити способности Homo Sapiens-a и преузети од њега улогу креатора.

\section{1 Трансхуманизам}

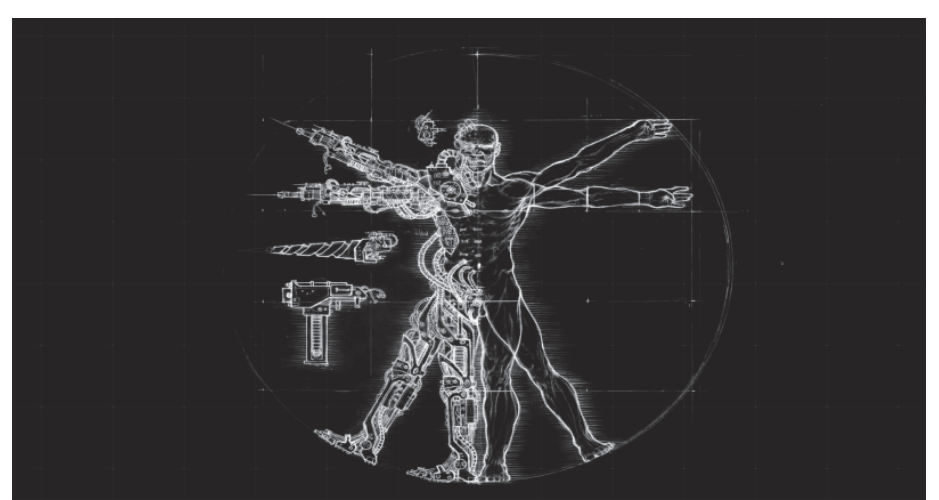

Слика 1: Трансхуманизам 
У тренутку када смо неопозиво носиоци креативности, одговорност нам налаже да поставимо питање: Како да наставимо да креирамо, а да избегнемо могућу деструктивност? Критичари идеја трансхуманизма групишу своје ставове у осам базичних аргумената (Veličković 2009: 2).

Аргумент преузимања улоге божанства. У теолошкој форми, критички став је изнет од стране Ватикана, 2002. године у изјави која промену генетског идентитета човека сматра радикално неморалном, обзиром да је њен производ „инфрахумано биће“. Секуларну форму заступају биолози, са ставом да клонирање и генетски инжењеринг на људском ембриону носе неприхватљив ризик, што се показало у експериментима на животињама.

„Фонтана младости“ аргумент, односи се на критику става о могућем пребацивању информација којима располаже ум појединца на биолошки млађи организам, чиме се постиже нека врста бесмртности.

Тривијализација људског идентитета

Аргумент генетске поделе се односи на социоекономске поделе (богатих и сиромашних), односно генетски „побољшаних“ и „непобољшаних“.

Опасност за морал и демократију обухвата аргументе о нарушености етичких принципа.

Дехуманизација - „Франкенштајн аргумент“.

Насилни еугенизам - аргумент еугенетског рата.

Егзистенцијални ризик - „аргумент Терминатор“.

Из наведеног се може закључити да се идеје трансхуманизма не односе само на аспект појединаца. Оне широко задиру у разматрања постхумане цивилизације и односе се и на културолошка разматрања. Њима припадају и идеје о развоју космичке технологије и колонизације, о ширењу живота универзумом и досезању „омега“ тачке, како ју је означио претеча трансхуманистичког покрета, Пјер Тејар ду Шардин (Pierre Teilhard de Chardin).

\section{2 Аналитичка психологија}

Да ли би се основне поставке трансхуманизма и проблеми са којима се овај покрет сусреће могли подвести под 
формулацију: трансхуманизам је изазов за нашу креативност? Да ли ћемо стварати вођени етичким ставом према новоствореном или ћемо упасти у замку неодговорне интелектуалне радозналости и властите ароганције? Психолошка теорија Карла Густава Јунга (Carl Gustav Jung), аналитичка психологија, међу првима препознаје потребу за креативношћу као једну од базичних људских потреба. У овој теорији се настојања сваког појединца сматрају значајним за унапређење колективног нивоа свести. Истовремено, препознато је да се многи феномени који су својствени индивидуи могу уочити и на нивоу културе којој припадамо, као и на нивоу читаве људске врсте. Кроз призму аналитичке психологије можемо да дођемо до нових начина сагледавања парадигме идеја и ризика трансхуманизма. Многоструки концепти ове теорије могу да буду оквир овог разматрања, а од посебног значаја су следећи:

- баланс између психолошког принципа логоса и психолошког принципа ероса,

- динамика између соларне и лунарне савести,

- Јунгов поглед на два различита типа свести,

- феномен „прометејског нагона“",

- метода амплификације,

- психолошке интерпретације књижевних и других уметничких дела која су релевантна за ову тему и др.

\section{2. Дијалог: Трансхуманизам у светлу аналитичке психологије}

Концепти аналитичке психологије су широко примењивани у критичким освртима на трансхуманизам, а користе их и припадници трансхуманизма, најчешће у репликама својим опонентима. Разумевање ових концепата је значајно не само као алатка за илустрацију одређених идеја, већ и као средство за препознавање ризика одређених теорија. Истовремено, присуство психолошке мисли у полемикама везаним за трансхуманизам, пружа већу сигурност и шири простор за могућа креативна решења у нашем развоју у будућности. 
2.1 Соларна савест и лунарна савест

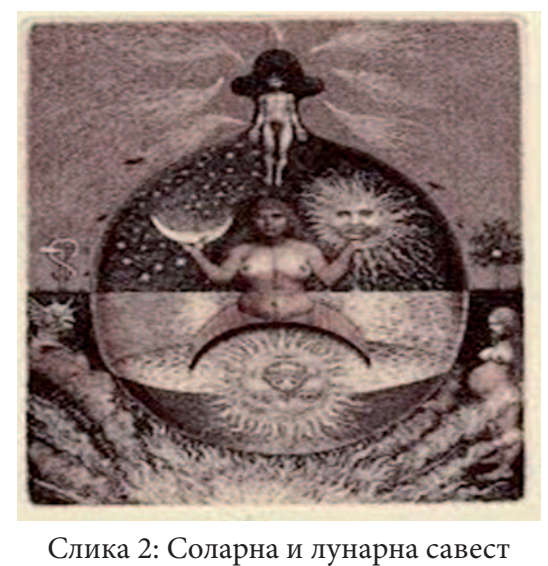

Како да останемо свесни онога што радимо? Иманентни представник Јунгове школе, теолог и аналитичар, Мари Стајн (Murray Stein), један је од аутора који се бави овим питањем. У свом делу Соларна савест, лунарна савест, аутор се бави моралним и етичким поступањем. По њему, соларна свест је унутрашњи глас или унутрашњи водич којег препознајемо кроз доминантне обрасце мишљења и понашања особе у њеном свесном животу. Он сматра да су наши доминантни свесни обрасци углавном идентични са онима који владају у колективу у коме живимо. Из овог разлога, соларна савест представља скуп социјалних правила и обичаја, устаљених навика и очекивања у нашој култури. Она, дакле, говори о законима и правилима који управљају културом, а које већина углавном усваја и као важећа ограничења у понашању појединца (Stein 1993: 24). Очигледно је да у овом принципу „групно“ узима превагу над „индивидуалним“ и да се личне жеље морају повиновати законима културе. „Соларна савест захтева од нас одговорност према друштву, она обухвата законе и правила доминантних образаца групе и налаже нам да ова правила поштујемо чак и у најинтимнијим односима (Stein 1993: 25)“. Препознајемо је у оквирима принципа мушкости - логоса. Кршење закона соларне савести ће код већине особа проузроковати осећај кривице и социјалне анксиозности, а биће пропраћено и 
осећајем отуђења од породице, групе вршњака или племенске групе. Свесно доживљавање појединца ће бити пребојено осећањем изолованости и усамљености.

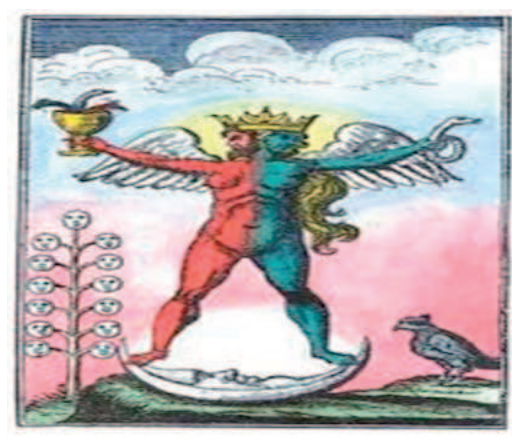

Слика 3: Соларна и лунарна савест

Лунарна савест је инстинктивни унутрашњи осећај којим откривамо базичне разлике између доброг и лошег. Она се повезује са психолошким принципом женскости. Дубље од личних, културолошких и социолошких одређења, она проистиче из архетипских аспеката људске природе. Њени водичи су инстинкти, често и телесни доживљаји који упућују на етичко вредновање - доброг и лошег. Кретање стазом ове врсте савести, не обухвата само ужи пут - пут моралног перфекционизма; њоме се крећемо ка целовитости и комплетности. Проблеми ове врсте савести се не повезују са осећањем кривице, моралне инфериорности и отуђености, већ са телесним симптомима, психосоматским поремећајима,осећањем анксиозности, ноћним морама, доживљајем прогањања и лудилом (Stein 1993: 61). Суштина разлика соларне и лунарне савести се може приказати као „љубав према закону“ (соларна савест) и „закон љубави“ (лунарна савест) (Stein 1993: 56).

Лунарна савест се сматра ранијом формом савести, она се успоставља пре него што је могуће доживети психолошке феномене кривице и кајања. Обзиром да се она испољава кроз телесне феномене, претпоставља се да је њен корен у симпатичком нервном систему. Структура Ја (која ће бити неопходна за успостављање соларне савести) извире из овог система, садржатеља бројних несвесних садржаја, али над њим нема контролу. 
2.2 Ерос и логос

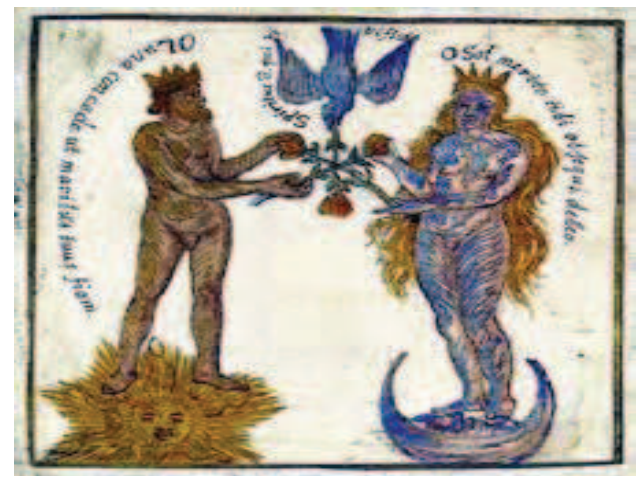

Слика 4: Ерос и Логос

Поменули смо да два облика савести имају повезаност са женским и мушким психолошким принципом. Почетак људског живота се одвија под окриљем мајчинског, женског - у симболичком смислу, а најчешће и у објективном. Мајчинска љубав је та која отвара пут психолошког развоја, уводи људску јединку у свет односа са другим припадницима људске врсте. Као у културолошком периоду матријархата, тежи се прихватању и успостављању хармоније међу различитим бићима и у односу са природом. Следећа фаза се одвија у односу са очинском фигуром на индивидуалном плану, а у култури одговара патријархату. Овде се у односима успоставља хијерархијска структура (по старости, роду и сл.) чиме је одређена и позиција моћи, односно - послушности. Ризик ове фазе је успостављање духовне атмосфере која није у складу са природним поретком, а даљим фаворизовањем оваквог стања долази се до етике која се може означити као opus contra naturam (Stein 1993: 67).

У Јунговој теорији се сматра да су ерос и логос два типа психолошког функционисана, мушки и женски. Они су независни од биолошке - полне датости. Ови принципи коегзистирају у психи сваке особе на комплементаран начин. Свака особа у психолошком смислу носи ову хетеросексуалност и ова датост нас прати током целог живота. Јунг наглашава да је веома значајно да ови психолошки фактори у нашем 
животу имају узајамну усклађеност, да опстају на избалансиран начин. Слабост или пренаглашеност једног од аспеката представља пут ка проблему. Постојање једног и другог аспекта се приписује дубоко укорењеним психичким предиспозицијама? Мушки пронцип се назива Логосом² ('logps), а женски Еросом ${ }^{3}$ ('irps или 'cros). Бавећи се етимологијом ових речи, Ендрју Самуелс (Andrew Samuels) повезује појам Логос са логичношћу, интелектом и постигнућем, речју и рационалношћу, а Ерос, у грчкој митологији Психин љубавник, означавао би повезаност (Samuels 2002: 259). Према Јунговом цитату, „појам Ероса се може изразити модерним терминима као психичка повезаност, а појам Логоса као интересовање за објекат... Мушкарац се обично задовољава само „логиком“. Све што је „психичко“, „несвесно“ и слично, њему је одбојно; то сматра нејасним, небулозним и болесним... За жену је обично важније да зна шта мушкарац осећа према нечему, него да спозна сам објекат“ (Jung 1978: 123-125). „Ерос има функцију да уједињује оно што Логос рашчлањује“ (Jung 1978: 132). У одређењу нашег идентитета, веома је значајна заступљеност особина једног и другог спектра. У аналитичкој литератури се сусрећемо са одрећењима попут „слабо развијеног“ Ероса код мушкарца ${ }^{4}$ или „високо диференцираног“ Ероса код мушкарца, „пасивног Логоса“ код жене, „претерано развојеног Логоса“ код жене и сл.

Ова два принципа, спектар женскости и спектар мушкости, присутни су, према Јунгу, не само у психи појединца, већ у свему што је наше културно наслеђе и у свему што је продукт наших активности у култури у којој живимо. На пример, математичка теорија припада Логосу, а аналогно мишљење и креативност која из њега проистиче - Еросу.

2 Грчка реч lógos се преводи као реч, говор, говореґе, дискурс, мисао, спремност да се начини избор, пребројаваюе.

3 Античка Грчка познаје реч е́рш или érōs као једну од четири речи које се у нашем језику, као и у већини других језика индо-европске групе преводе као тьубав.Остале три речи су storgē (бторүи́), philía

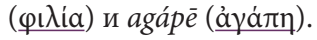

4 На примеру Виктора Франкенштајна, знаног јунака новеле Мери Шели, можемо да усвојимо становиште да је овде приказан мушкарац „неразвијеног“Ероса. 
Слична одређења се приписују науци о култури и психологији, класичном и романтичарском стилу у уметности. Дакле, у основи дихотомије су процеси стварања у којима се један односи на фокусирану свест и поштовање чињеница, а други на имагинацију, фантазију, игру. Ова апстрактна одређења могу да буду јасније осликана кроз атрибуте и метафоре који им се приписују. Функције Логоса су активност, асертивност, он је продирућ и тежи интелектуалном, у интересовањима је усмерен ка конкретном објекту. Ерос је пасивни садржатељ, емотиван, рецептиван, субмисиван, повезујућ, увек заинтересован за успостављање односа. Са освртом на античко наслеђе, аполонијски принцип је принцип Логоса, а дионизијски - Ероса. ${ }^{5}$ На сличан начин можемо да сагледамо симболику небеских тела, у митологији бројних народа: Сунце представља мушки, а Месец - женски принцип. У аналитичкој психологији, мушкост је: ум, интелект, Анимус, а женскост је дах живота, душа, Анима. Исто одређење је и у дихотомији духа и душе, свесних и несвесних процеса.

Значајно је да разумемо да су ова два принципа једнако вредна, да сваки од њих обитава у нашем свесном или несвесном делу психе и да су наши бројни емоционални проблеми током живота често повезани са занемаривањем или отуђењем од једног од аспеката, при чему обично долази до пренаглашености другог, супротног аспекта.

\section{3 Трансхуманизам и биоконзервативизам}

Наведене парадигме аналитичке психологије, препознатљиве су у полемикама везаним за покрет трансхуманизма. Оне се претежно воде између заговорника трансхуманизма и критичара овог покрета, припадника биоконзервативизма. У

5 Аполонијско-дионизијско је појмовни пар који су сковали немачки романтичари, Ф. Шлегел (F. Schlegel) и Ф. В. Шелинг ( F. W. Schelling), ради тумачења класичне грчке културе. Поља значења која су покривена именима Аполона и Диониса, код старих Грка нису била у јасно супротстављеном односу. У периоду романтизма у књижевности и уметности, аполонијско представља светлост, разум, форму, меру, а дионизијско представља таму, емоционалну екстазу, безобличност и безмерност. (Leksikografski zavod Miroslav Krleža, http://www.enciklopedija.hr/). 
јесен 2004. године, Френсис Фукујама (Francis Fukuyama), професор политичке економије и члан Председништва Америчког одбора за биоетику, објавио је текст у коме је изнео да је једна од актуелно најопаснијих идеја на свету - трансхуманизам. Сматра га најрадикалнијим ослободилачким покретом 20. века, обзиром да настоји да ослободи човека од његових биолошких ограничења. По њему, људски организам не функционише увек оптимално, али та чињеница је неизбежна - иманентна је људској природи. Тешкоће и ограничења се могу ублажавати уз помоћ медицине, технологије, философије и других знања, али се „несавршености“ не могу сматрати ограничењима. Адаптација на различитости је природно људско искуство, а трансхуманизам представља опасност јер се бави модификацијом суштине људскости. Опонент професора Фукујаме је оснивач Светског удружења трансхуманиста ${ }^{6}$, Ник Бостром (Nick Bostrom), научни истраживач на пољу теорије вероватноће, философије науке и етичких импликација технолошког развоја на људску врсту. Обзиром да човечанство очекују радикалне промене, Бостром позива на креирање новог социјалног поретка у коме ће се одговорно доносити важне одлуке. Сматра да економија слободног тржишта не испуњава принципе праведности који су неопходни за имплементирање идеја трансхуманиста. У реплици на Фукујамин текст, он каже: „Нема разлога да људи са измењеним или унапређеним капацитетима не буду исто тако једнаки пред законом, нити постоји икаква подлога за претпоставку да ће постојање ових људи морати да подрива векове правног, политичког и моралног побољшања“" (Bostrom 2004, 2).

Двојица аутора нам се обраћају из различитих сфера савести, под утицајем различитих принципа - ероса и логоса. Фукујама истиче значај живота у складу са природом, са прихватањем различитости, са етичким разматрањем „чудног ослобођења", како назива трансхуманизам, али и са емоционалним вредновањем ратних катастрофа последњег века.

Бостром се креће сферама закона, морала, он је у сфери логоса, али са видним пренебрегавањем сфера ероса. Да ли

6 Удружење је основано 1998. године. 
је могуће да написана правна норма донесе праведност комплексној људској групи? Треба ли да нас брине став да смо савременици највећег успона политичког и моралног живота у историји? Да ли смо сведоци неосвешћене ароганције или неодговорне идеализације садашњости? Како да поверујемо да ћемо бити хуманији ако у овом тренутку не препознајемо сопствена ограничења? Човечанство је увек скупо плаћало изједначавање закона и етичког поступања, у даљој и ближој прошлости, а плаћа је и данас. Ова трагична чињеница је актуелна реалност живота у земљама развијеног и неразвијеног света, у истој мери.

\section{4 Два облика мишљења}

У наставку разматрања модела аналитичке психологије који пружају оквир за разумевање теорије и критика трансхуманизма, осврнућемо се на две врсте мишљења које Јунг сматра значајним у нашој оријентацији према свету. Један облик мишљења назива директивним, логичким, мишљењем које се пролагођава стварности. Њиме, каже, мислимо у речима, прилагођава сукцесију објективно реалних предмета и слике у нашој глави следе једна другу у каузалном низу. Овај тип мишљења је оруђе културе и довео је до успеха прилагођавања којем можемо да захвалимо за модерну емпирију и технику. Друга врста мишљења одводи од реалности у фантазије о прошлости и будућности. Овде се „слика тиска уз слику, осећање уз осећање и све јасније се усуђује да се појави једна тенденција која се ствара и поставља не онако како је то стварно него како би се можда желело да буде“ (Jung 2005: 28-29). Ово мишљење је блиско сањарењу у коме је изграђен језички облик мање присутан. Јунг пише да је ,језик првобитно систем емоционалних и имитативних гласова; то су гласови који изражавају престрашеност, бојазан, гнев, љубав итд, они који подражавају шумове елемената, жубор и гргољење воде, одјекивање грмљавине, хујање ветра, звуке животињског света итд. И најзад они који представљају комбинацију гласа опажања и гласа афективне реакције“ (Jung 2005, 24-25).

Оба аспекта мишљења, и феминин и маскулин су веома важна и о томе говори реченица: „Тајна културног развитка 
јесте у покретљивости психичке енергије и у њеној способности да мења своја тежишта“ (Jung 2005, 28).

Сумирајући досадашње наводе о јунговским погледима на дихотомије у обликовању свести, интелекта и разума са једне стране, а развоја имагинације, чулности и интуиције са друге стране осврнућемо се на утицај који врши култура у њиховом фаворизовању. Особине које се поистовећују са мушким, вековима су у култури сматране супериорним. Имагинација, чулност и интуиција, особине које припадају женском спектру, сматране су мање вредним. На плану појединца, овакви културни утицаји подржавају једностран развој и умањују могућност хармоничног самоостварења личности. „Та хипертрофија мушких црта у патријархалним културама водила је све већем удаљавању од женског, па чак и својеврсној мизогинији, која није својствена искључиво мушкарцима, већ може присутна и у несвесном жена. Владајући андролатријски вредносни систем већ столећима делотворно обезвређује, како преко својих мушких, тако и преко својих женских поданика, не толико жену пер се, већ женско у свим његовим магијско-митолошким димензијама. Како је жена у свему женственија од мушкарца, она је, уз узајамну сагласност припадника оба пола, одређена као инфериорна... Андролатрија и мизогинија - присутне не само у ставовима обичног човека, већ и у философским и у религијским, на Западу и на Истоку, током последње 2-4000 година“ (Popović 1995:7-8).

\section{3. Оковани Прометеј - - предикција ризика трансхуманизма}

Увод: 1818. године, у Лондону је објављена новела анонимног аутора, Франкенштајн или модерни Прометеј. Предговор овом делу је написао П. Б. Шели (Percy Busshe Shelley) и започео га реченицом: „Доктор Дарвин и неки немачки философи претпостављали су да догађај на основу којег је написан овај роман није немогућ." Не улазећи у разматрање физичких чињеница, а полазећи од претпоставке да је основа приче 
плод маште, Шели не сматра да је прича „само измишљање низа натприродних ужаса“" (Šeli 2004: 220).

Да ли овај коментар наговештава помисао о томе да садржај новеле може да има предиктивни значај? Два века касније, у садашњем тренутку, нема никакве сумње да је предиктивни дар аутора указао на развој науке ка циљу стварања нове врсте у еволуцији човека и појаву теорије и праксе трансхуманизма.

\section{1 Културолошка сагледавања}

Млада ауторка, Мери Шели (Mary Shelley), уткала је у ово дело свој креативни таленат, лична формативна искуства, широко образовање и отвореност ка критичком мишљењу. Њено дело осликава културу времена у коме је живела, а које у књижевности припада периоду романтизма. У њему сазнајемо о социјалном поретку, породичним односима и вредностима, подели родних улога и подели економских класа. Сагледавамо и претпостављени однос људи према „чудовишту“, према нечему што је другачије и према важећим естетским мерилима - ружно. Франкенштајн ће временом постати инспирација за бројне студије у области феминизма, психоанализе, политике, теорије књижевности, језика, историје, економије, трансхуманизма и поремећаја у развоју.

Франко Морети (Franco Moretti) ће анализирати унесрећену креатуру коју је створио Виктор Франкенштајн, упоредо са представом грофа Дракуле. Његов оквир је Марксова теорија о отуђености пролетаријата; Дракула је представник немилосрдног поседника, капиталисте, а биће из новеле Мери Шели представља обесправљену радничку класу. Ове две фигуре су, према овом аутору, метафоре друштвених класа 19. века. Међу њима влада велика тензија која производи друштвену анксиозност, а обе фигуре имају архетипске предиспозиције (Moretti 1982:67-82).

Анка Власолоплос (Anca Vlasopolos) износи богату психолошку анализу ликова новеле, уз став о превази маскулиних принципа над фемининим, што покреће низ неповољних догађања у радњи. Њена анализа се односи и на политичка сагледавања у којима запажа да издвајање више класе, са њеном 
жељом за моћи, узрокује низ инцидената који ће довести до пропасти породице Франкенштајн. Новела се може разумети и као метафора расних и класних сукоба у њеној домовини, Јужној Африци, те је 1955. године у овој држави била забрањена књига ауторке Мери Шели (Vlasopolos 1983: 125-35).

Ен К. Мелор (Anne K. Mellor) ће се у критичкој биографији Мери Шели посебно усмерити на културолошка сагледавања везана за убрзан технолошки развој и експанзију научних открића у времену у коме је књижевница живела. Мелорова ће изнети интерпретацију да ауторка новеле има критички став према тадашњем научном развоју у коме препознаје изразиту превагу маскулиног, а залаже се за феминин став (емпатије, неговања) у унапређењу живота коришћењем науке. Користећи парадигму ероса и тогоса, фемининог и маскулиног принципа, Мелорова у новели препознаје тензију између женске снаге природе и рационалних, објективних, пренаглашено мушких карактеристика Виктора Франкенштајна (Mellor 1988: 38-51).

Постоје критике које културолошком и психолошком аспекту придодају и биолошки. Стивен Џеј Гоулд (Stephen Jay Gould), палеонтолог и еволуциони биолог, 1994. године је анализирао лик чудовишта у новели, као и реакције окружења на њега у раду „Монструмова људска природа“. Он сматра да се чудовиште налази у суровој замци међу људима због дубоко укорењене, наследне биолошке предиспозиције код људи и других сисара, а то је инстинктивно аверзивно реаговање према озбиљно малформисаним индивидуама. Међутим, сматра аутор, култивисање људи под утицајем окружења, даје другачије ефекте. „Природа нас опскрбљује предиспозицијама, док је култура та која обликује различите резултате. “7 Гоулд је вођен Дарвиновим ставом: „Ако беду наших сиромашних не узрокују закони природе, већ наше институције, велики је наш грех.“ (Gould 1994: 1-5).

Дајана Лонг Ховелер (Diana Long Hoeveler) је понудила опсежан преглед феминистичке критике, а обухватила је њиме и психоаналитичку критику (Hoeveler 2003: 45-60).

Мери Јакобус (Mary Jacobus) написала је чланак „Постоји ли жена у овом тексту?" (“Is There a Women in This Text”) у коме

7 У оригиналу текста се користи израз: nature versus nurture. 
каже да се њена радозналост не задржава на хостилном очинском принципу - Виктору у идентификацији са божанством, већ на представи одсутне, мртве мајке, симболизоване стањем усамљености чудовишта. Чудовиште је лишено љубави и дословно је без мајке, прижељкује да буде прихваћено, а бива одбачено и креће се ка насилништву (Jacobus 1986: 83-109).

Најпознатија ученица Жака Лакана (Jacqes Lacan), бугарска емигранткиња Јулија Кристева, изнела је и аналитичку интерпретацију новеле. Она је, такође, инспирисала бројне друге психоаналитичке критике (Hoeveler 2003: 50-52).

\section{2 Психолошка биографија Виктора Франкенштајна}

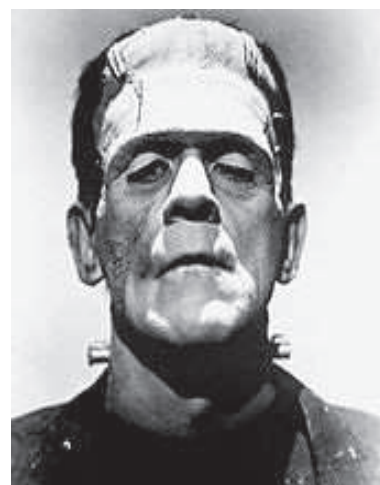

Слика 5: Креација Виктора Франкенштајна

Размотрићемо портрет Виктора Франкенштајна са аспекта јунковских принципа психолошке мушкости и женскости. Пред нама је човек који се у младости дивио и посвећено бавио изучавањима Парацелзуса и других истраживача у алхемији. Израстао је у младог научника који оставља за собом ова знања, води га рационална научна страст и креће се у сферама логоса. Какве податке нам пружа Мери Шели за сагледавање његове психолошке биографије?

Почнимо са описом који упућује на Викторову слику родитеља и личног детињства: „Ниједно људско биће није могло провести детињство срећније од мога. Моји родитељи су били надахнути нежношћу и благошћу.“ (Šeli 2004: 26) „Услед ове дубоке свести о томе шта дугују бићу коме су поклонили 
живот, додајући уз то велику нежност која их је обоје надахњивала, може се замислити да сам, док су ме у сваком часу мог детињства учили стрпљењу, милосрђу и самосавлађивању, био тако вођен на свиленом повоцу да ми је живот личио на непрекидно уживање.“ (Šeli 2004: 21) Чини се да у сржи ових доживљаја постоји клица личне ексклузивности и да се пут ка гордости може достићи многим пречицама.Можемо ли, такође, да претпоставимо постојање породичног модела презаштићивања, али и наглашеније самоцентриран став одраслог човека који истиче „дуг“ у односу на властито постојање?

Додатну илустрацију о раном устројству Викторове ароганције пружа опис о уласку Елизабете, његове усвојене сестре, а касније и веренице, у породицу Франкенштајн. Пред долазак девојчице чија је мајка умрла на порођају, дајући јој живот, Викторова мајка каже: „Имам леп поклон за свог Виктора, сутра ће га добити“. Цитат се наставља Викторовим коментаром: „Па кад ми је сутрадан представила Елизабету као обећани дар, ја сам, са детињом озбиљношћу, буквално протумачио њене речи, и сматрао сам Елизабету својом - својом да је штитим, волим и браним. Све хвале које су јој биле упућиване, примао сам као да су указиване мојој својини...Никакве речи ни изрази не би могли описати њен однос према мени - била ми је више него сестра, пошто је до смрти имала да буде моја.“ (Šeli 2004: 23)

Ово је веома особен почетак грађења односа у коме је тешко замислити реалну узајамну размену и упознавање. Тешко је претпоставити да се на позицији „другог“налази друго људско биће и да у односу могу постојати елементи реципроцитета. „Поседнички“ манир готово да опредмећује Елизабету у Викторовом доживљају, а у простору узајамног огледања, Елизабета је средство којим он додатно увећава доживљај личне вредности. Можда је баш овај цитат најбоља илустрација укорењивања хибриса - гордости који ће бити окосница на Викторовој животној путањи.

У психи будућег научника постоје острва великих развојних ризика. У исто време, он је надарен мислилац, уочава и темељно описује разлике између појава. Његов опис разлика у личностима између њега и Елизабете представља изузетан 
приказ разлика између психолошких категорија мушког и женског. „Елизабета је била сталоженије и мирније природе; али и поред све своје ватрености, ја сам био способан за већу марљивост, и више ме је обузимала жеђ за знањем. Она је волела да се удубљује у нестварне песничке творевине; а у величанственим и чудесним пределима који су окруживали наш швајцарски дом... налазила је широко поље за дивљење и усхићење. Док је моја другарица озбиљна и задовољна духа посматрала изглед ствари, ја сам уживао у истраживању њихових узрока. Свет је за мене била тајна коју сам желео да одгонетнем. Радозналост, озбиљна тежња да докучим скривене законе природе, радост слична усхићењу кад би ми они били откривени, спадају међу најранија осећања којих могу да се сетим.“ (Šeli 2004: 25)

Неопозиво, поље психолошког логос-а је код Виктора изузетно развијено. Оно што отвара ризике за његову личност јесте велика неравнотежа у односу за заступљеношћу ероса. Као што у партнерским везама често наилазимо на комплементарност у заступљености особина личности, тако се и у значајним пријатељским везама срећемо са овим узајамним „допуњавањем“. Клервал, Викторов најбољи пријатељ, има далеко развијенију страну психолошког женског; он је експресивнији у показивању осећања, заокупљен размишљањима о етичким категоријама „доброг“ и „лошег“, а не само о логичким поделама на „тачно“ и „нетачно“. Он је маштар и романтик, склон игри и креативним импровизацијама у позоришним представама и маскарадама. У тексту препознајемо његову радост и његову патњу, склоност ка неговању другог и високу пожртвованост у томе.

Викторов емоционални живот је представљен другачије: „Моја нарав је понекад била плаховита, а узбуђења жестока; али по неком закону мога темперамента то ме није наводило на детињаста занимања, већ је изазивало жарку жељу да учим... да докучим тајне неба и земље... моја истраживања су ипак управљена ка метафизичким или, у највишем смислу, ка физичким тајнама света." (Šeli 2004: 26)

Надменост његове природе, што укључује склоност ка обезвређивању другог, уочава се на многим странама текста. „Неуки сељак посматрао је елементе око себе, и упознао је њихову практичну примену. Ни најученији филозоф није 
знао много више...Разматрао сам препреке и утврђења која су, изгледа, спречавала људска бића да уђу у тврђаву природе... (Šeli 2004: 28)“. Ривализирање и дубока рањеност у ситуацијама у којима себе не процењује као супериорног, склоност ка јаком презрењу - веома су својствени његовој личности.

Експанзивне тенденције су све јаче и његов доживљај реалитета сада превазилази људско искуство. Терминима аналитичке психологије, доживљава инфлащију, слом својих индивидуалних психолошких граница и поистовећивање са улогом „створитеља“. Виктор је „био изненађен што сам међу толиким генијалним људима који су своја истраживања управили ка истој науци једино ја био одређен да откријем тако чудну тајну....успео сам да откријем узрок рађања и живота; и још нешто више, био сам у стању да подарим живот беживотној ствари.“ (Šeli 2004: 41)

Продор ових садржаја ће довести до слома у структури његове личности. Ранија тенденција ка једностраности, у смислу баланса између ероса и логоса, сада ће довести до одсуства женског принципа у његовом психолошком бивствовању. Његов однос према новоствореном бићу је у потпуности лишен бриге, неге, етичке одговорности и, свакако, лишен љубави, што приказује већ први сусрет између њих: „Али сада, кад сам завршио, дивни сан је ишчезао а срце ми је испуњавао неизмеран ужас и одвратност. Не могавши да поднесем изглед бића које сам створио, побегох из собе... Можда је говорио, али ја нисам чуо; једну руку је испружио, као да ме задржи, али ја побегох и јурнух низ степенице.“ (Šeli 2004: 48) Његово несвесно јасно осликава стање у коме се нашао; сан који у том тренутку уснива, подвлачи смрт представе женског у његовој души, смрт његове аниме. „Причинило ми се да видим Елизабету, у пуном здрављу, како шета улицама Инголштата. Усхићен и изненађен, загрлих је; али кад спустих први пољубац на њене усне, оне мртвачки пребледеше; црте лица јој се изменише, и учини ми се да држим у наручју мртво тело своје мајке; тело јој је обавијао покров и ја опазих како црви миле у наборима платна. Тргох се из сна ужаснут.“ (Šeli 2004: 48)

У стању психолошке дезинтеграције, Виктор - „створитељ“ одиграва карикатуралну улогу божанства. Продор овог архетипа у његову психу доводи до фрагментације; не само да нема одговорност према бићу које је створио, он овог пута 
нема ни план за своје даље активности. Покушава да се врати пређашњем животу, уз утисак да користи негацију као психолошку одбрану, скрива се у нади да ће заувек моћи да га избегне.

Новостворено биће започиње живот лишено мајчинства у конкретном и симболичком смислу. Рођено изван тела жене, лишено неге, љубави, подучавања о преживљавању, оно преживљава. Интелектуални капацитети му омогућавају да као самоук усвоји многа знања, а емоционална искуства су му трновита. Поседује особину емоционалне привржености и нада се испуњењу ове потребе у сусрету са партнерком, што му Виктор ускраћује. Ово биће не започиње живот испуњено мржњом; његова злодела покреће ланац емоционалних повреда. „И ја сам осећао љубав, она ми је узвраћена мржњом и презиром.“ (Šeli 2004: 157)

Дуго одлагани дијалог између Виктора и бића које је створио, уводи нас у нови аспект сагледавања динамике личности. У духу мотива „двојника“, популарног у периоду „тамног романтизма" или готске новеле, Виктор и чудовиште се могу посматрати као носиоци супротстављених особина у оквиру једне личности. Они би представљали „светлу“ и „тамну“ страну особе, део личности који живи особине које фаворизујемо и део личности у пољу несвесног, са особинама које свесно одбацујемо. Терминима аналитичке психологије, овај дијалог би могао да се сагледа као дијалог између Викторовог свесног дела, његовог Ја структуралног елемента (Виктор) и између дела његових несвесних садржаја, његове Сенке (чудовиште). У овом дијалогу чудовиште каже: „Робе,...сети се моје моћи... ја сам твој господар - послушај ме!“" (Šeli 2004: 157) Овим је изражена важна психолошка чињеница; у стању фрагментисаног Ja, Сенка загосподари психичким животом појединца. Њени делови живе својим аутономним животима потискујући наша свесна настојања. Ово је још једна илустрација Викторовог слома. Хипотетички, да се дијалог одиграо много раније, што би психолошком терминологијом могло да се означи као дијалог између Сенке и очуване структуре Ja, отворила би се могућност за креативну трансформацију и развој личности. Прорада садржаја Сенке је један од базичних поступака у терапијском поступку, а новела Мери Шели нас 
на још један начин упућује у оно што чини неуспех у креативности. Какав би био наставак ове новеле да је Виктор био у контакту са новоствореним бићем, да га је ослушкивао, надзирао, водио рачуна о његовим осећањима, учио, интересовао се за његова размишљања? Новела би припадала другом књижевном жанру. Каква би особа био Виктор да је раније промишљао о својој једностраности у свесном ставу, да је нашао начин да савлада своју ароганцију, да проради неке од аспеката личног несвесног? Претпоставимо да би, узимајући у обзир и његову обдареност, био веома плодотворан научник.

\section{4. Прометејска жудња}
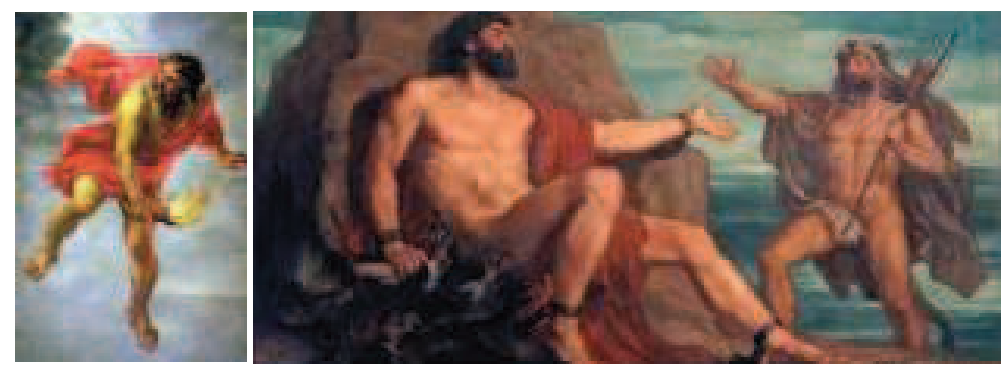

Слика 7. и слика 8: Прометеј

Тема прометејске жудње је присутна у литератури Аналитичке психологије, као и у бројним дискусијама на тему трансхуманизма. Које облике овог феномена препознајемо? Под прометејском жудюом подразумевамо:

1. жељу да се униште традиционалне форме у култури,

2. истрајност у задржавању традиционалних форми, у супротности са тежњама модерних уметника и научника,

3. уношење нових форми у култури, уз велики лични ризик,

4. самодеструктивност при буђењу отуђења од културе.

Мит о Прометеју је из јунговске перспективе анализирало неколико аутора. Најпознатија је студија Бетине Кнап (Bettina Knapp) која је 1979. године у аналитичку теорију увела термин Прометејев синдром. По овој ауторки, мит о Прометеју представља метафору рођења и развоја структуре 
Ја у појединцу. Размотрени су и негативни аспекти испољавања прометејске жудње. Поред античког мита, Кнапова се у оквиру ове теме бави и Гетеовим Фаустом (Knapp 1979).

Постоје, међутим, нови погледи у којима су опсежније разматрани негативни аспекти овог синдрома. Рад Луиса Монтиела (Luis Montiel), PROLES SINE MATRE CREATA (Пойомсивво настиало без учешћа мајке), инспирисан је радом најпознатијег архетиполога нашег времена, Џејмса Хилмана (James Hillman). Овде је Прометејев синдром интерпретиран као психолошко застрањивање у маскулином принципу које развија гордост ( хибрис) и ароганцију у односу на принципе женскости све до развоја мизойиније.

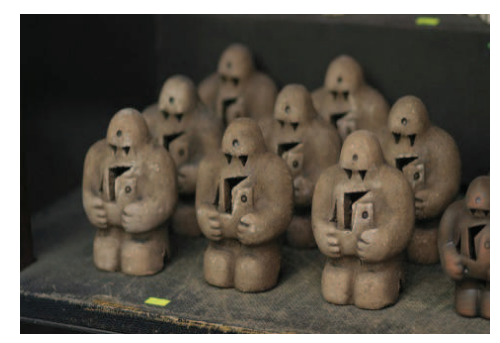

Слика 9: Голем

У овој студији је кроз дијахрону раван изнет осврт на „бића“ која су у митологији разних народа, у философским правцима и у књижевности „рођена“ без учешћа женског, односно - мајке. Још од времена Античке Грчке (узимајући у обзир митологију, философију, књижевност), наследили смо црте мизогиније и хибриса, сматра Хилман. Подсетимо се рођења Атине и бројних античких јунака, чији настанак Хилман коментарише: „Мајка није родитељ ономе што се назива њеним дететом, већ само неговатељица ново-засађеног семена које расте. Отац је онај који „креира“... Може постојати родитељ без присуства мајке..." писао је Хилман у свом критичком осврту на ову појаву 1972. године (Montiel 2013: 7). То су уверења Аристотелове природне философије, Галенове медицинске мисли. Ова мисао се провлачи кроз нашу културу, обзиром да има два извора: хеленски и јудејски, а наставља се кроз хришћанство. На пример, бог 
Јахве је створио Адама, а затим Еву из своје твари. У каснијем периоду, појављују се легенде о Голему и Хомункулусу. Ове традиције имају своје корене у средњем веку, али она о Голему , направљеном од блата, у јеврејској традицији, може се датирати уназад (иако је напознатија са краја 16. века). Хомункулус припада алхемијској и кабалистичкој традицији и повезана је са идејом артефицијалне, вештачке креације људског бића у лабораторији човека. Парацелзус (Paracelsus) пише „...да је могуће да је људско биће рођено без потребе за коришћењем женског тела и природне мајке. Могу да одговорим да за уметност алхемијских процедура, као и за природу, то уопште није немогуће. Штавише, потпуно је могуће. ${ }^{8}$ Да се ово испуни, потребно је ставити сперму човека у затворену реторту, оставити је да ферментише у коњском урину и пустити да прође кроз процес путрефакције кроз најмање 40 дана... док биће не постане живо, док не почне да се креће и да се тресе, што се лако може уочити. Тада ће, до извесне мере, бити слично људском бићу, али провидно и без тела. Ако је у овом стадијуму мудро храњено свакога дана супстанцом Arcanum sanguinis humani у току 40 дана, уз одржавање исте температуре у коњском урину, тада ће постати живо људско дете, са свим удовима, као свако друго дете које је родила жена, само мање. Можемо га звати хомункулус ( homunculus), и мора бити подизано са истом посвећеношћу и бригом као свако друго дете све док не достигне године у којима постаје разумно. Ово је највећа тајна коју је Бог подарио на знање смртом и грешном човеку“, пише Парацелзус.

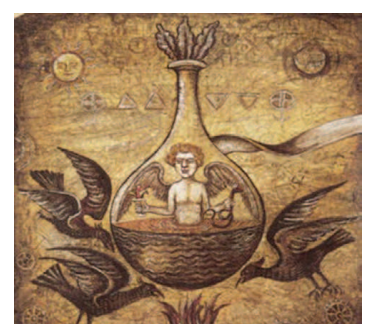

Слика 10: Хомункулус

8 Цитат преузет из текста Луиса Монтиела, Proles sine matre creata: The Promethean Urge in the History of the Human Body in the West. 


\section{1 Различитост у интерпретацији мита}

о Прометеју и исходима методе амплификације

Прометеј је титан који се борио на страни богова јер је знао за исход битке - видео је будућност и Зевсову победу након десетогодиђњег рата (Grevs 1987, 127-129). Већ на овом нивоу, интерпретације познавалаца митологије се разликују. Према Замаровском, Прометеј се бори против сународника, Титана, јер је „отелотворење храбрости, поносног пркоса и отпора старом поретку... као и због љубави за слободу и човекољубивости“ (Zamarovski 2002, 418-419). Помогао је рађању Атине из Зевсове главе. Она га је научила архитектури, астрономији, математици, пловидби, медицини, металургији и другим знањима и вештинама. Ова знања он преноси људима и изазива љутњу Зевса који није желео да се способност људи до те мере увећава. Успевши да се заузме за људе код Зевса, он другим својим делањем поново изазива љутњу божанства. Лукавством наводи Зевса да од људи прима на жртву мање вредне жртвене дарове. Зевс индиректно кажњава Прометеја одузимајући људима ватру. Користећи лукавство, Прометеј сада краде ватру са Олимпа, враћа је људима, а себе излаже дуготрајном прогону и тешком кажњавању од стране Зевса рата (Grevs 1987: 127-129).

Прометеј се сматра оцем људске врсте, „спада међу најстарије а при том увек живе симболе борбе за напредак и срећу човечанства“(Zamarovski 2002: 419); не само да је учествовао у физичком настанку људи, већ их је „научио да живе свесним и разумним животом“ (Zamarovski 2002: 419). Учинио их је мање зависним од временских неприлика, научио их је да рачунају, читају и пишу. Уз његову помоћ, људи су могли телесно да јачају и да се духовно уздижу.

Од времена Антике, Прометеј је био инспирација песницима и мислиоцима. Обрадама овог мита су се бавили Гете (Goethe), Бајрон (Byron), Шели (Shelly), Жид (Gid) у књижевности, а био је инспирација сликарима, музичарима и филмским уметницима.

У полемикама везаним за трансхуманизам, различите интерпретације сегмената овог мика модификују и начине психолошке методе амплификације. Амплификација 
представља врсту ширења представе сна, имагинације или дневне фантазије, при чему се у њу уносе материјали који не припадају сневачевој личној историји. Дакле, амплификација подразумева повезивање представа сна са материјалом културе - уметношћу, књижевношћу, сликарством, фолклором, митологијом, религијом и сл. (Hall 1978: 37). У редоследу амплификовања се почиње са личним материјалом, овоме следи културолошки, а потом долази архетипски.

На примеру истог мита, поред поменутих разилажења, наилазимо и на ставове да „прометејски став“ или „прометејска жудња“ у трансхуманизму не представљају само жељу за усавршавањем природе, већ садрже у себи и аспирацију ка моћи, успостављању владавине над новоствореним. Напомиње се да Прометеј није само оспособио људе за корисна достигнућа; он их је, такође, онеспособио у могућности да виде сопствену будућност. Да ли би ова способност људи додатно унапредила и њихова техничка и духовна знања? Прометеј је исту способност ускратио и боговима, а хипотезе о могућим значењима овог поступка су бројне.

Полемика се наставља у ставовима да је овај јунак људима подарио ватру. Опоненти наводе да су људи већ имали ватру коју им је Зевс у срџби ускратио, а Прометеј поново вратио. Да ли је у овом поступку имала превагу Прометејева жеља за помагањем људима или изражавање неслагања са Зевсом и порив да га још једном „надигра“? Наилазимо на ставове да је Прометејево опонирање Зевсу колатерално довело до бенефита за људски род - поновног поседовања ватре коју има Зевс сада није ускратио и поред тешког кажњавања Прометеја... Прометејевом грешком се не сматра намера да оспособи људе да контролишу природу, већ то што се усудио да се супротстави Зевсу, моћнијем натприродном бићу од себе самог.

У теорији Аналитичке психологије, Мари Стајн Прометеју приписује знатан удео лунарне савести. Препознаје његову емпатију у односу на људски род, који је презрен, а мора да буде покоран сили бога Олимпа. Прометејеву лунарну савест овде осликава покушај да спаси живот, човечанство, природни поредак. У оносу на овог хероја, Зевс одиграва улогу тиранског господара, оног који је злопамтило, осветољубив 
и који брутално кажњава. По њему, „Зевс креира Прометеја, а супротно је такође тачно“ (Stein 1993: 104). Овај пар представља динамику соларне и лунарне савести. Значајно је да истакнемо да Стајн сматра да је изворна мотивација Прометеја у његовој лунарној савести. Касније, као представник аутономног комплекса Ја, он до екстрема појачава све што је у почетку био позитиван мотив, пун је самовоље и огорчења због нарушене праведности, ескалира његово ривализирање са Зевсом и вероватна је жеља да стару очинску власт замени властитом (Stein 1993: 107).

Мери Шели је у динамици односа између Виктора и чудовишта произвела сличну поставку. Виктор у младости обухвата елементе лунарне савести, што је превасходно препознатљиво у његовом бављењу алхемијом. Алхемијски процес се у Аналитичкој психологији сматра метафором процеса индивидуације. Обзиром да он подржава психолошки развој, самоостварење човека, односно развој у складу са његовим природним датостима, могу му се приписати својства фемининог. Међутим, у Виктору се догађа трансформација која би набоље могла да буде илустрована и објашњена следећим Јунговим цитатима:

„Алхемија је освит природнонаучног доба, која је помоћу демонијума научног духа у нечувеној мери приморала природу и њене силе да служе човеку. Из духа алхемије створио је Гете слику 'натчовека' Фауста, а овај натчовек водио је Ничеовог Заратустру... Овде леже прави корени, секуларни, душевни припремни процеси за оне чиниоце који су данас делатни у свету. Техника и наука су заиста завладали светом; али да ли је душа нешто тиме добила, то је друго питање“ (Jung 1987: 38)... Мисао да се 'вештином' ('Kunst') може постићи нешто што је преко природе типично је алхемијска“ (Jung 1987: 45). 
4.2 „Љубав је енергија“ - предикције ду Шардена

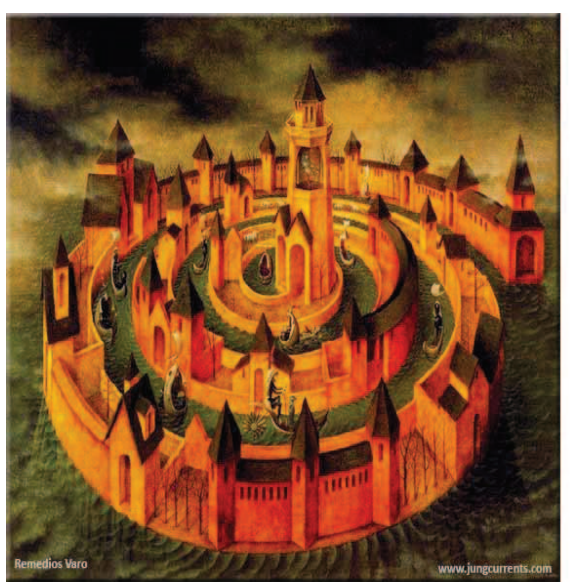

Слика 11: Целовитост

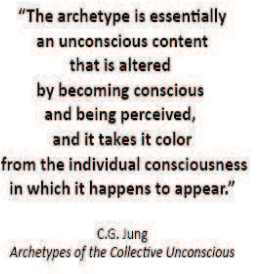

У давној прошлости, од културе Вавилона, па до доба Просветитељства у Европи, сматрало се да је једна од главних функција снова - њихов предиктивни значај. Током двадесетог века, Аналитичка психологија ће постати једна од ретких грана науке која узима у обзир и могућу предвиђајућу функцију снова. Исти ставови се могу применити и за садржаје имагинације, као и за део дневних фантазија. У овом контексту, занимљиво поље истраживања представља предиктивност уметничких дела ( као што је књижевни рад Мери Шели на Франкенштајну), научних теорија и философских идеја насталих у ранијим периодима. На првом месту, у тематици везаној за трансхуманизам, важно је поменути дела Пјера Тејарда ду Шардина (Pierre Teilhard de Chardin), философа, језуитског свештеника, палеонтолога и геолога. Ду Шардин (1881-1955) је био један од водећих аутора у теорији о будућности људске еволуције. Радио је у време када компјутерска наука није постојала, као ни бројна достигнућа данашње биологије, али је један од првих који је разматрао тему трансхуманизма и сматра се, предвидео развој интернета (Steinhart 2008: 1). Развио је теорију Омега тачке (Oтеga Point Theory) по којој универзум еволуира и конвергира ка крајњем стадијуму које одговара божанском уређењу. Иако је 
извршио велики утицај на теоретичаре трансхуманизма, ретко је помињан у њиховој литератури. Док су данашњи трансхуманисти и католичка црква оштро међусобно супротстављени, де Шардин је трансхуманистичке идеје развијао у контексту религије и бранио их пред конзервативним струјама хришћанства. У својој теорији, говори о степену комплексности система и његовом прогресивном увећању у еволуционом процесу. Овај образац запажа и у ступњевима развијања људске свести коју означава као сваку врсту менталне активности.

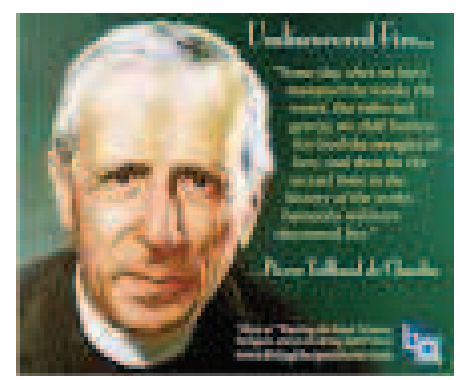

Слика 12: Тејар ду Шардин

У свом сложеном разматрању, де Шардин анализира и предвиђа пренос информација у различитим системима: атомским, биолошким, можданим и у вантелесним органима (генетска технологија и роботика). Сматра да ће нам генетски инжењеринг омогућити да управљамо нашим телесним развојем, укључујући и развој мозга и да ћемо моћи да контролишемо наследне факторе. Он тврди да људска интелигенција треба да руководи еволуцијом путем генетског инжењеринга и залаже се за етички адекватан облик еугенике: „Током наредних векова ће бити неопходно да се открије и развије племенити људски облик еугенике, са стандардом достојним наших личности. Еугеника примењена на појединце доводи до еугенике примењене на друштву“.9 Предвиђања наредних епоха у де Шардиновом делу укључују факторе религије, спајање човечанства и технологије и повезана су са ширењем духовности на планети. Овоме следи експанзија ка универзуму,

9 Цитат преузет из рада Телиар де Шардин и трансхуманизам (Steinhart 2008: 6). 
ширење информација ка свемиру и епоха телесног васкрсења. Последњи стадијум је Омега тачка у којој се сустичу идеје хришћанства и пантеизма (Steinhart 2008: 13).

Занимљиво је повезати ове идеје са идејама које настају половином 20. века, а које и данас нису широко распрострањене у нашем поимању света; у аналитичкој литератури наилазимо на термин syneidesis, a to је форма савести која „биолошкој савести“10 и која је додатно значајна у оквиру теме трансхуманизма. Сматра се да је она уткана у сваку форму живота и да организује протоплазму сваке ћелије. Њена улога је повезана са очувањем и развојем живота појединца, као и сваке биолошке врсте (Stein 1993: 63).

Сличном дискурсу припада ду Шарденово виђење назначајнијег елемента у процесу еволуције, а то је љубав. „Љубав је енергија. То је природни динамизам , значајан за еволуцију... афинитет бића ка другом бићу није својствена само човеку. Код свих сисара се препознаје у различитим модалитетима: сексуална страст, родитељски инстинкт, социјална солидарност... " У даљем тексту, он се осврће на ставове Николаса од Кузе (Nicolas de Cusa), средњевековног философа: „Вођени снагама љубави, фрагменти света проналазе један другог тако да свет почиње да постоји..“ и наставља: „Ово није метафора; ово је много више од поезије. Љубав је, са свом својом суптилношћу, ништа више и ништа мање него више или мање директан пут означен на срцу елемента психичком конвергенцијом универзума на себе“ (de Chardin 2002: 264-265).

4.3 Како еволуира еволуција?

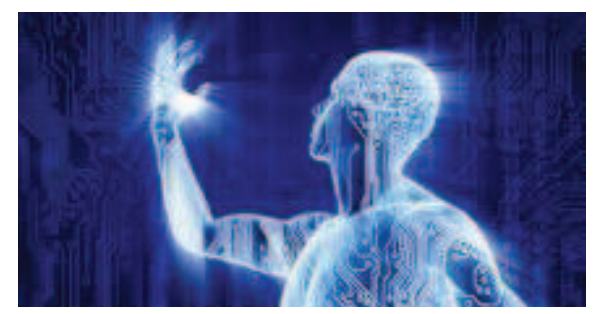

Слика 13: Трансхуманизам

10 Термин је 1950. године увео Константин фон Монаков (Constantin von Monakow). 
Ду Шардин је писао: „Човек је открио да он није ништа друго него еволуција која је постала свесна себе саме“, а еволуција „није ништа друго него континуиран раст... 'психичке' или 'радијалне' енергије." ${ }^{11}$ У критичком осврту на трансхуманизам, Курувила Пандикату (Kuruvilla Pandikattu) предлаже да након интензивне технолошке и моралне еволуције, ревидирамо овај став у: „Еволуција је постала способна за свесно ширење или елиминисање себе саме" (Pandikattu 2008: 50). Наиме, процес мењања нашег окружења путем укључивања роботике и компјутерске науке је већ дуго наша реалност. Пројекти у којима се истражује и мења људски геном започети су, такође и сигурно је да неће бити обустављени. Они се баве усавршавањем постојеће људске врсте, али досежу и до могућности стварања нових врста. Бројне су предности које ови пројекти доносе нашој култури и креативни замах не треба спречавати. Са друге стране, значајно је, како наводи Курувила Пандикату, да се не понашамо као Виктор Франкештајн. Продукти наших интелектуалних залагања не смеју бити лишени озбиљног промишљања о нашем етичком поступању.

Предностима и ризицима трансхуманизма, као и погледома на даљу еволуцију, бави се и Филип Вердо (Philippe Verdoux). У контексту разматрања промена у култури, Вердо сматра да је идеја о сталном прогресу илузорна, те да наш песимистичан поглед на будућност није нереална. Сa друге стране, аутор сматра да футуролошка визија трансхуманизма, у овом тренутку представља најпоузданији пут ка суочавању са оним што нас очекује (Verdoux 2009: 49). Извесније је да ће, у односу на друге могуће опције, футуролошки програм трансхуманизма бити примењен. Наш је задатак да до највеће могуће мере умањимо незаобилазан пораст могућности за самоуништење. Морално преиспитивање, истиче и овај аутор, „повећава наду да ћемо опстати у будућности“ (Verdoux 2009: 62).

11 Цитат преузет из рада Трансхуманизам: Избор је и дале наш (Pandikattu 2008, 50) 


\section{5. Закључак}

Трансхуманистички покрет ће неопозиво наставити да се развија, што човечанству може да донесе велике користи. Од велике је важности, међутим, да паралелно са овим процесом, приступимо и другом важном задатку: потребно је да стално продубљујемо своју свест о ономе што радимо и да избегнемо могућу деструкцију.

Поглед на будућност је могуће градити из различитих перспектива: из садашњости или прошлости, у кругу логичког, рационалног закључивања или путем имагинације и интуитивног сазнања. Јунак новеле Мери Шели, Виктор Франкенштајн, данас представља парадигму непромишљеног поступања у науци; његово велико залагање на плану интелектуалног постигнућа и пасионирана посвећеност превазилажењу људских ограничења, отуђили су га од закона природе, принципа ероса и лунарне савести. Приказан садржај новеле се данас може сматрати предикцијом могућих ризика у покрету трансхуманизма.

Можемо да закључимо да не постоји јединствен поглед на будућност, што не представља проблем у овој теми. Ризици проистичу из евидентних разлика у препознавању странпутица у даљој еволуцији и, сходно томе, дивергенције у ставовима који би нас штитили од деструкције. Психолошка интерпретација актуелних проблема у теорији и критици трансхуманизма нуди јасноћу у сагледавању ризика и даје путоказ за разумевање тешкоћа са којима ћемо се срести. Пут између разумевања и саживљавања са психолошким чињеницама је непредвидив; овај процес није дефинисаног трајања, може да има „застоје“, а нема ни гаранције да сваки појединац има капацитет да га искуси. Психолошки увиди се не могу увести као „декрет“, па је неопходно да разумемо значај појединачне одговорности - не само у сагледавању теме трансхуманизма, већ у раду на себи, на препознавању личног баланса соларне и лунарне савести. 


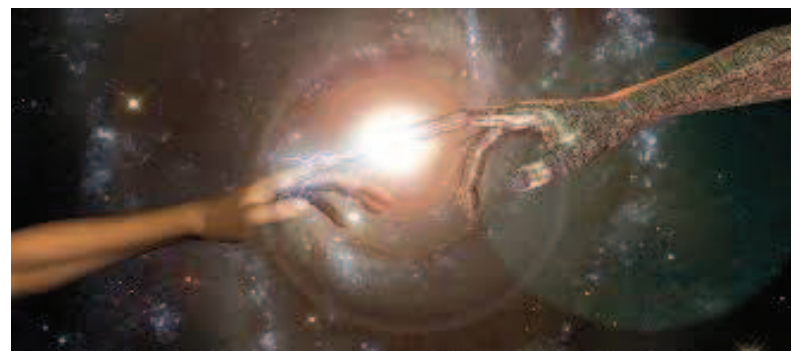

Слика 14: Будућност

\section{ИЗВОРИ И ЛИТЕРАТУРА}

Birx, James H. 2015. Frankenstein: Critical Reflections. Предавање на Филолошком факултету у Београду, одржано 21.12.2015. (accessed January 10, 2016.)

Bostrom, Nick. "Is Transhumanism the Wordl's Most Dangerous Idea?" Betterhumans Staff, 10/19 (2004): 2-34 http://www.nickbostrom. com/papers/dangerous.html (accessed January 4, 2016.)

Bostrom, Nick. "In Defence of Posthuman Dignity". Bioethics, Vol. 19, No. 3 (2005): 202-214. http://www.nickbostrom.com/ethics/dignity.html (accessed January 3, 2016.)

Veličković, Vladica. “Transhumanizam - za i protiv”. Astronomski magazine (2014). http://www.astronomija.co.rs/ivot/1264-transhumanizamza-i-protiv.html (accessed January 10, 2016.)

Verdoux, Phillipe. “Transhumanism, Progress and the Future”. Journal of Evolution and Technology, Vol. 20 Issue 2 (December 2009): 49-69. http://jetpress.org/v20/verdoux.htm (accessed January 10,2016.)

Vlasopolos, Anca. “Frankenstein's Hidden Skeleton: The Psycho-Politics of Oppression”. Science-Fiction Studies, 10 (1983), 125-35 (accessed February 8, 2016.) http://knarf.english.upenn.edu/Articles/vlasopol.html (accessed February 11,2016.)

Gould, Stephen Jay. The Monster's Human Nature. Metalab: English Department, 1994. http://www.ibiblio.org/schools/rls/garner/britishlit/nature.pdf (accessed February 11, 2016.)

Grevs, Robert. Grčki mitovi. Beograd: Nolit; Priština: Jedinstvo, 1987.

de Chardin, Teilhard. The Phenomenon of Man. New York: Perennial, An Imprint of Harper Collins Publishers, 2002.

Zamarovski, Vojtjeh. Junaci antičkih mitova. Beograd: Alinari, 2002.

Jacobus, Mary. “Is There a Woman in This Text?". Reading Woman: Essays in Feminist Criticism. New York: Columbia Univ. Press, 1986. 83-109 http://knarf.english.upenn.edu/Articles/jacobus.html (accessed 
February 13, 2016.)

Jung, Carl Gustav. "Civilisation in Transition”. Collected Works, vol. 10. London: Princeton University Press, 1978

Jung, Carl Gustav. Paracelzus kao duhovna pojava. Čačak: Alef, 1987. Jung, Karl Gustav. Simboli preobražaja. Beograd: Atos, 2005.

Knapp, Bettina. The Prometheus Syndrome. New York: The Whitston Publishing Company, 1979

Mellor, Anne K. "Making a Monster". Mary Shelley: Her Life, Her Fiction, Her Monsters. Chapter 2 of New York: Methuen, 1988, 38-51 http://knarf.english.upenn.edu/Articles/mellor2.html (accessed February 13, 2016.)

Montiel, Luis. "Proles sine matre creata: The Promethean Urge in the History of the Human Body in the West". Asclepio, Revista de Historia de la Medicina y de la Ciencia. 65, 1 (2013): 001 https://www.academia. edu/3740979/Proles_sine_matre_creata._The_Promethean_Urge_ in_the_History_of_the_Human_Body_in_the_West

Moretti, Franco. "The Dialectic of Fear. New Left Review". 136 (Nov.Dec.1982): 67-85. https://www.scribd.com/doc/149635035/FrancoMoretti-The-Dialectic-of-Fear (accessed February 8, 2016.)

Pandikatty, Kuruvilla. "Transhumanism: The Choice Is Still Ours". Pacific Science Rewiew, Vol.10, No. 1 (2008): 49-57. http://psr. kangnam.ac.kr/psr_bk_iss/vol10/03_H-01_KKuruvilla_49-57_. pdf (accessed January 12, 2016)

Popović, Velimir B. Psihologija ženskog, Jungovo nasleđe. Beograd: Nolit, 1995.

Samuels, Endrju. Jung i njegovi sledbenici. Beograd: Zavod za udžbenike i nastavna sredstva, 2002.

Stein, Murray. Solar Conscience, Lunar Conscience. Asheville: Chiron, 1993.

Steinhart, Eric. "Teilhard de Chardin and Transhumanism". Journal of Evolution and Technology, Vol. 20 Issue 1 (2008): 1-22. http://jetpress.org/v20/steinhart.htm

Hall, James. Clinical Uses of Dreams: Jungian Interpretation and Enactments. New York: Grune and Stratton, 1978.

Hoeveler, Diane. Frankenstein, Feminism, and Literary Theory. Milwaukee: Marquette University, 2003. http://epublications.marquette. edu/cgi/viewcontent.cgi? article=1051\&context=english_fac

Šeli, Meri. Frankenštajn, Moderni Prometej. Beograd: Utopija, 2004. 


\section{Bojana Stamenković Rudić}

\section{TRANSHUMANISM AND ANALYTICAL PSYCHOLOGY}

The paper presents a critical overview of the transhumanist movement from the aspect of Analytical Psychology.

The ideas and risks of this practice are examined through the overlapping field with some of the basic paradigms of Jung's teaching: solar and lunar conscience, psychological aspects of eros and logos, as well as direct and phantasmatic thinking. The views of relevant authors were used in the theory of Analytical Psychology, starting from the creator of this school, all the way to our contemporaries. The paper also presents a psychological interpretation of the literary work that is relevant to this topic, Frankenstein: Or the Modern Prometheus, author Mary Shelley. Predictive charactercan be attributed to this work in relation to the theme of transhumanism, and this work inspired the emergence of numerous studies that deal with the perception of this novel through the diverse cultural aspects. This paper deals with a part of these critical reviews, with an emphasis on topics that can be linked to the possible risks of the transhumanist movement. Within this subject, the myth of Prometheus inspired different ways of its interpretation; we encounter differences in his understanding between members of psychological thought, and especially in the dialogue of patrons of transhumanism and bioconservativism. Dichotomies in the way of perceiving Prometheus syndrome and Prometheus cravings lead to different approaches in the application of amplification, one of the methods of work in analytical psychology, in the examination of psychological material. A field is opened here, which polarized views in the consideration of the idea of transhumanism and the whole of our culture.

In conclusion, the necessity of balancing the presence of masculine and feminine qualities in our engagement with ideas, emotional experience and in our conscious action is pointed out. Neglecting the feminine psychological principles, currently present in our culture, could in the future lead to the realization of present risks and large destructive shifts.

Key words: transhumanism, analytical psychology, Prometheus syndrome, psychology of female and male. 